\title{
"A Space of Time that is Always Filled with Moving": Cinematic Modes and the Writing of Gertrude Stein
}

\author{
PATRICIA MAY
}

\section{Abstract}

The relationship between film and literature has always tended to be examined in terms of the effect that literary works have had upon cinema. The reverse - that is, the way cinematic techniques might filter into and find expression in works of fiction - has largely been overlooked by scholars. In this essay I examine the work of the American modernist Gertrude Stein, relating her experimental prose to cinematic modes of looking and of experiencing time. Focusing on Three Lives and Tender Buttons, I argue that Stein not only draws upon philosophical ideas linked to film, but appears to be attempting to replicate cinematic experience as text. Cinema was at this time becoming enormously important to the American experience, as part of a new visual culture linked to photography, advertising, and mass entertainment. I argue that, in drawing on film in this way, Stein is able to capture and replicate a distinct form of "Americanness" - the fast-paced, visually busy, but also fragmented nature of urban life in the early twentieth century.

Much has been written on the impact of literature upon film, on filmic adaptations of literary works and the ways in which literary structures have found their expression in the cinema. The same cannot be said of the reverse: very few scholars have explored in any depth the impact that cinema has had upon the nature of literary forms, or the ways in which film has "infiltrated, contaminated and altered" literature (Murphet and Rainford 2003). This essay is intended as an examination of the manner in which film can be said to filter, consciously and unconsciously, into the structures and preoccupations of American literary modernism. Focusing on Three Lives and Tender Buttons, I 
argue that Gertrude Stein's writing is informed by the cinema in a number of complex ways: stylistically, in her experimental prose, but also in her treatment of time and of the act of looking. In arguing this, I want to draw on ways in which the visual culture that emerged in the early twentieth century has found its way into the very way we perceive and categorise the world around us. I am interested in the way in which this cinematic culture might be thought of as a particularly American phenomenon, or as particularly American in its importance - and how, in turn, the cinematic quality of Stein's writing might be linked to questions of cultural identity.

At this point we might note the tendency within criticism to look to Stein's critical writings when approaching her less accessible works. Tender Buttons, in particular, tends to be read through the prism of much later writings, in an attempt to supply it with the coherent meaning that it so obviously refuses to court. This is a useful and convenient way to approach Stein, and one that I intended to draw on. It is, however, an approach that requires caution. Literary celebrity was something that Stein craved from the beginning of her career. Her critical writings almost without exception exist in the form of public lectures, delivered to the Oxford and Cambridge literary societies, and while on tour in America, in the 1930s. In these lectures, Stein explains her theories of literature and the processes of composition that informed several of her works. But while highly useful, these lectures are also problematic, in that their extremely public nature marks them partly as exercises in self-mythologising. Given her repeated references to herself as "if you like being a genius" ("Portraits and Repetition" 1934, 107), I feel that what she tells us in the 1930s, about how she was structuring and thinking about her writing twenty years earlier, is to be taken with a grain of salt.

I am not interested so much in how Stein's work might be said to dovetail with avant-garde cinema, or even with various developments in the visual arts (Stein associated herself with Cezanne and Picasso in Paris - her "Portraits" are sometimes said to be cubist [Hoffman and Murphy 1992, 2; Walker 1984, 20]). Rather I would like to focus more on the idea of cinema itself, on the sort of philosophical and perceptual problems associated with it, and how these might be said to filter into Stein's work.

\section{Motion, temporality, time: Three Lives and Stein's "continuous present"}

Early critical writing on cinema focuses on the fact that it moves, on film as a part of "the cultural and conceptual fascination with questions of motion" (Marcus $2007,18)$. Cinema as an art form was interesting because it was alive, and was 
therefore ephemeral, in a way that no art form had ever quite been before. It could be made to capture life in a way that seemed as realistic as if these captured images had been lived. Yet what the cinema shows us is only ever an illusion: not living but mechanical, a series of frames being fed through a machine. A paradox exists in the liveliness, but intangibility of the medium. As Virginia Woolf wrote in 1926: "We behold [the images on screen] as they are when we are not there. We see life as it is when we have no part in it" (Woolf 1926, 167). Bound up with these questions of the cinema as motion are, of course, ideas of time. The very movement of the cinematic image means that film is one of the only forms of art that is experienced in "real time", and one that can manipulate the sense of time as we experience it. Film alone has the potential to create an illusion of the present moment as present, that is, paradoxically vanishing even as it is experienced: any given image in a film disappears almost before we have a chance to process it. From this we might conclude that early theorising about cinema places the new form within a discourse of fading and decay, linking it with the seeming impossibility of capturing life in art - ideas that modernism in general was fascinated with, and with which Stein's Three Lives very much engages.

This critical fascination with cinema as a moving art becomes highly important when considered alongside early twentieth century conceptions of what it meant to be American. "Americanness" by this point had come to be linked to movement, speed, velocity: with Taylorism and the production line, with the development of the automobile, with vibrant metropolises like New York, and with the supposedly countless opportunities they offered for social progression and for the gaining of wealth (Murphet 2003, 72). Cinema was made up of images that moved; and America (which, less than two decades after the invention of the medium, would come to be so ubiquitously linked to the film industry), was a country that moved. Stein apparently recognised this, and she takes the idea up in several of her critical lectures. "[T]he American thing," she declares, "is the vitality of movement" ("Portraits and Repetition" 1934, 103). In "The Gradual Making of The Making of Americans", she explains further:

Think of anything, of cowboys, of movies, of detective stories, of anybody who goes anywhere or stays at home and is an American and you will realize that it is something strictly American to conceive a space that is filled with moving, a space of time that is filled always filled with moving. ("The Gradual Making of the Making of Americans" 1934, 97).

Stein, connects movement (and here, "the movies") to an American cultural identity. This is highly significant in that it marks the cinema as an essentially American form. It might thus be argued that Stein's appropriation of cinematic 
forms in her writing is linked to her cultural identity, to her "Americanness". It seems possible that she is picking up ideas that exist as a kind of cultural static during the time in which she is writing.

In 1934, Stein described the sort of style she was attempting to achieve in Three Lives as "including everything and a beginning again and again within a very small thing" ("Composition as Explanation", 26). She explains that she set out to create the sense of a "continuous present", apparently meaning that she wanted to cause the reader to be completely immersed in the experience of the text, to the point that they forget that what they are reading is a linear narrative, becoming caught in the "present" of the story rather than its "past" or "future" ("Composition as Explanation", 25). Importantly, she repeatedly refers to the "naturalness" of this development. Stein sees herself as a writer articulating modes of being very specific to the time in which she is writing, as tapping into a sort of cultural "zeitgeist". The experience of time that Stein intended to create with her "continuous present" seems to strike a chord with the way we experience time in the cinema. In her later writings she suggests that this similarity was not deliberate, but the result of the fact that "each of us in our own way are bound to express what the world in which we are living is doing" ("Portraits and Repetition" 1934, 105). We might therefore argue that the cinema filters into Three Lives unconsciously, at the level of language. Stein's technique of "beginning again and again within a very small thing" can be likened to a loop of film being fed through a projector. Her play with syntax and repetition seems to mirror film broken down to its bare components: individual cells which vary only slightly in what they depict, but nonetheless create the illusion of a living, beating, moving present.

"Melanctha", one of the novellas in Three Lives, sees Stein develop a distinctive prose style which uses repetition to stall our sense of the passage of time. In doing so, Stein seems to create a style that mimics in its structure and 'feel' the technical qualities of a strip of celluloid. Film as a material is essentially made up of an image that is repeated again and again, with tiny incremental differences. When the film is "read" by a projector, the fragments run together and the repetition causes the image to appear on the screen as a moving, living whole. In Stein's "Melanctha", the repetition of specific words and entire phrases works in a similar way. It is possible almost to pull any passage out to demonstrate this, but we might focus on an interior monologue from Melanctha's lover, Jeff Campbell:

Always Jeff knew, sure, Melanctha was wrong in what she had said that night to him, but always Melanctha had had deep feeling with him, always he was poor and slow in the only way he knew how to have any feeling. Jeff knew Melanctha was wrong, and yet he always had a deep 
doubt in him. What could he know, who had such slow feeling in him? What could he ever know, who always had to find his way with just thinking. (109)

This passage provides a good example of the sort of anaphora that characterises the novella as a whole. Anaphora is the repetition of a word or phrase at the beginning of successive clauses, and it is the near-constant use of this that makes Stein's style in "Melanctha" seem so distinctive. Ideas take much longer to develop in this novella than we might expect, because they are forced to loop back on themselves, in the same way that each image in a film is forced, however fleetingly, to refer to the image that has preceded it. In Stein's case, this repetition is intended to stall the flow of time, and thus cause us to be caught in, almost swept up by, the present moment.

Stein is also able to achieve a stalling of the flow of time in the novella through a play with tense. "Melanctha" is not written in the present tense, but the text has a tendency to use present-tense verbs, with a repetition of the "ing" sound featuring prominently. Thus, for instance, we have "he was really feeling" instead of "he really felt", "he was beginning to really have understanding" instead of "he began to really understand" (90). A sing-song texture emerges as a result of this which is significant in that it seems childish. It almost suggests that Jeff and Melanctha are not adults, that they are incapable of the sort of retrospective analysis that would be implied by "he began to really understand" and are experiencing the world with the simple directness of childhood. Time ceases to be something rational, linear and measurable and becomes, for them, something amorphous, loose, extremely present. (Though, it must be said, this play with tense can also be linked to primitivism in the work, to Stein's depiction of African-Americans as incapable of using language with sophistication).

"Melanctha" also reveals its indebtedness to film in some of the ideas that it plays out at the level of its plot: specifically, the idea that it is impossible to truly "know" or understand what seems present or tangible to us. This idea can be linked to the early philosophical conceptions of the cinematic image outlined earlier - as something ephemeral and slightly disturbing, showing us the world as it is when we are not present, creating a "reality" that is more beautifully real than life itself but that we can never touch or access. Regardless of how close they get to one another, Jeff and Melanctha seem not to be able to connect, and they are never able to experience their closeness without an anxious sort of intellectualising, a questioning of what each actually means to the other and what the feelings they are experiencing actually indicate. In its depiction of their relationship, the text is playing with a paradox: the moment as it is lived is passing too. As Charney puts it, for modernists, "The simple single moment was conceived as inconceivable both because the moment is always already gone 
before we can perceive it and because the single moment is therefore extended beyond any one moment" (Charney 1998, 30). This is a profoundly cinematic way of viewing time and human experience.

Stein's play with technique in "Melanctha" does not fully achieve what she claims to have intended. She appears to have meant the aesthetic of the "continuous present" to create a sense of cinematic velocity - a sense of time experienced as it is in reality, and therefore, as it can be in the cinema. But Murphet notes that the use of technique in The Making of Americans actually "tended to stretch events out over intolerable periods" (Murphet 2003, 78), a critique which can definitely be extended to Three Lives and to "Melanctha" in particular. Stein's play with syntax and repetition does not produce the feeling that we are caught in the present moment as it is lived, but rather that we are in a kind of limbo, ceasing to move at all. "Melanctha" is in many ways difficult and tedious reading, with its seemingly unending stretches of "I am certainly now feeling" and "I am certainly now beginning to be feeling". If we forget "future" and "past" in the text it is because we are bogged-down in the language, caught in circular passages where repetition has the effect of stripping words of meaning. The shape of Stein's prose might well recall a strip of film, but she fails utterly to capture film's vivacity and liveliness in the "time-sense" of her work.

\section{Looking and excess: Tender Buttons}

Murphet contends that the "aesthetic break into "movement-images"" is not achieved until Tender Buttons, Stein's highly experimental book-length prose poem (Murphet 2003, 78). This work is inherently cinematic, and appears to be about the act of looking. Tender Buttons essentially consists of a series of portraits, not of individuals, but of household objects and familiar rooms, made abstract, distorted, disconnected. It is almost as though Stein is attempting to unravel meaning: she begins with a recognisable noun, and then spins outwards in what seems to be a nonsensical stream of associations. The poems resist coherent reading, and Tender Buttons represents Stein at her most difficult and inaccessible. I want to argue that the work's disorienting stylistic qualities can be linked to the privileging and decentring of vision that comes about with the introduction of cinema and the rise of modern visual culture. They can also, as Murphet (2003) argues, be seen as an extension and refinement of the aesthetic of the "continuous present".

It is the belief of many critics that the introduction of cinema changed the very way that humans perceive and categorise the world around them. North observes that "a fundamentally different kind of visual experience is available 
to the modern eye" (North 2005, 178). Cinema is recognised as belonging to a broader cultural phenomenon: as Charney points out, it "comprehensively brought together the attributes of modernity's distractions and entertainments" (Charney 1998, 82). North (2005) links the rise of modern visual culture to development of advertising, to the modern metropolis as a visually busier space, even to the new sort of "looking" that comes with the advent of high-speed travel in trains and automobiles. With the rise of visual culture modernity itself becomes a "flashing, fleeting experience" like "the moment of shock" (Charney 1998, 47). The increased pace and variety of visual experience was held by theorist Walter Benjamin, and others to have actually altered the sensory organisation of human beings (Charney 1998, 47 - 48). North (2005), indeed, notes that this idea came to be so crucial to the thinking of twentieth century theorists that these "supposed changes to the human sensorium have come to represent modernity itself" (185). In light of this, the privileging and questioning of vision that Sitney (1990) finds in modernist writing takes on a new importance. According to Sitney, modernist literary works "stress vision as a privileged mode of perception, even of revelation, while at the same time cultivating opacity and questioning the primacy of the visible world" (Sitney $1990,2)$. This can be directly connected to the shift in the nature of visual experience brought about by the rise of modern visual culture, and the advent of cinema.

Stein herself notes the importance of looking to her project in Tender Buttons:

I did express what something was, a little by talking and listening to that thing, but a great deal by looking at that thing. This as I say has been the great problem of our generation, so much happens and anybody at any moment knows everything that is happening that things happening although interesting are not really exciting. ("Portraits and Repetition" 1934, 112 - 113, my emphasis).

Stein is no longer interested in "everything that is happening" - in narrative, in events, perhaps even in human relations, because "things happening although interesting are not really exciting". In Tender Buttons she turns her attention instead to the mute, still world of objects and spaces, bringing this to life in a vibrant, nonsensical, and definitely "exciting" way. I want to argue that Stein, whether intentionally or not, creates a sort of "looking" in this work that is actually mechanical, analogous to what the movie camera does, and not to what happens when the human eye "sees".

At this point I would like to mention theories of "cinematic excess", a concept that can help to illuminate what Stein is attempting to achieve. It refers to the idea that the cinematic image always captures more information than it means to: that it is impossible to control beyond a certain point what the camera sees, 
because it captures everything that is in front of it (Thompson 1986, 131). This is in contrast to the human eye - which does not "see" exactly what it sees, because the brain invariably processes and rearranges the information it receives into a coherent image. Excessive elements exist outside the limits of the film's intention, and are therefore both "counternarrative" and "counterunity" (Thompson 1986, 134). Thompson shows how seemingly trivial detail can distract the viewer, draw attention away from the narrative and thus work against the "meaning" of a film - producing a sort of odd parallel-reading that calls into question the ability of the image to make meaning at all (Thompson 1986, 138).

Examining Tender Buttons through this idea of excess might go some way towards explaining its difficulty, and even account for the fact that so many hesitate to approach this work critically without the prism of Stein's lectures for support. Of course this reading is drawing on theories that do not come into being until a good sixty years after Tender Buttons is written. But in attempting to create a sort of "looking" that mimics the mechanical, all-seeing eye of the camera, Stein's work necessitates the inclusion of excessive elements. It seems fairly simplistic to point out that Tender Buttons resists coherent meaning. If nothing else, bringing the concept of cinematic excess to the work allows for an analysis that goes at least a little way beyond this observation.

Syntactical play is taken to a new extreme in Tender Buttons: syntax is not only altered, but blown utterly apart. The work seems on a first reading to be made simply of random words, squashed together without punctuation. The syntactical play might be said to build on what we see in "Melanctha". In that novella, sentences are broken in a way that both captures the dialectical qualities of African-American speech, and disrupts our perception of the passage of time. Here, though, syntax is not simply fractured to produce a particular effect, but ripped apart, with phrases consisting of a jumble of words that do not follow a recognisable pattern and thus barely make sense ("There is no way to see in onion and surely very surely rhubarb and a tomato" [176]). The difficulty of the work seems to stem largely from this disunity, from the seeming randomness with which "sentences" are constructed. This fracturing of the work might be compared to other key modernist texts: The Waste Land by T.S. Eliot (1922), for instance, is also made up of fragments, and it too appears at times to be nonsensical. Yet certain definite themes, of decline, barrenness, and ennui, emerge when Elliot's poem is considered as a whole. The same cannot be said of Tender Buttons. The work has almost no thematic unity, because it resists meaning at the level of language. Unity perhaps only exists in its general structure: in the titles of each of the prose poems, which signal to us the fact that the work, if it is "about" anything, deals with the act of looking at ordinary spaces and objects, in a way that disconnects them from recognisable experience. 
Detail in Tender Buttons can be termed "excessive" because of its volume and apparent uselessness: it does not serve any discernable purpose beyond "offering itself for perceptual play" (Thompson 1986, 133). Stein jams fragmented glimpses of familiar environments into awkward or nonsensical clauses: "A single speed, the reception of table linen, all the wonder of six little spoons, there is no exercise" (190). The work is composed almost entirely of these frenetic, half-glimpsed images, which, though often quite beautiful, are also equally distracting and equally disorienting. Returning to the idea that Tender Buttons is about looking, we might remark that there is no one part of it as an "image" that our eye is directed to. This excess of detail makes it difficult to make critical judgements about the work. As Thompson (1986) writes, cinematic excess is extremely difficult to write about because "[a]nalysis implies finding relationships between devices", but excessive elements, perhaps because they are a by-product of the nature of the cinematic apparatus, "do not form relationships, beyond those of coexistence" (134).

Stein requires her readers, if they persist with the work, almost to drown in the barrage of imagery presented in Tender Buttons. The titles of the prose-poems are all that we are offered in the way of a concrete referent: "GLAZED GLITTER", "A BOX", "A RED HAT". The third chapter of the work, "Rooms", differs in that it is not composed of these short poems, but paragraphs which run together. This makes it the most interesting and frustrating section to approach. Without the titles, there is nothing to anchor or ground us in the text. Responses to this section seem likely to take one of two forms. Either we might suspend logic, the unconscious search for meaning in the piece, and "lose" ourselves in the language, in the barrage of imagery; or we might resist its dense meaninglessness, and thus immediately lose the ability to concentrate on it. If our response falls along the lines of the former, we can surely see what Murphet means when he suggests that this work represents the realisation of the cinematic "timesense" Stein was attempting to create in her earlier writings (Murphet 2003, 78). Tender Buttons can be seen to achieve the sense of the "continuous present", the feeling that, as we read, we are experiencing the present moment unfolding and vanishing, unfolding and vanishing, that Stein claimed she had created through her games of repetition in earlier novels. Tender Buttons, however, requires a very particular, open, detached style of reading in order to be successful in this respect.

Thompson (1986) points out that "most viewers are determined to find a necessary function for any element the critic singles out. For some reason, the claim that a device has no function beyond offering itself for perceptual play is disturbing to many people" (133). In the end, Tender Buttons may be unsettling because the images or signs it contains are not actually meant to convey anything in particular, but are instead a sort of excess, the result of an attempt on Stein's 
part to see the world anew, through mechanical eyes. A kind of meaning arises out of the juxtaposition of the images with one another, but this "meaning" is uncertain, disturbing, a function of the way we are trained to read (and view) images rather than the result of a specific idea Stein means to advance. It may be, in fact, that in Tender Buttons, "The stamp which is not only torn but also fitting is not any symbol. It suggests nothing" (191).

\section{Conclusion}

Despite the fact that Stein only claimed a passing interest in cinema, and claimed this only in retrospect, ideas about looking, and the new ways of "seeing" brought about as a consequence of modern visual culture, nevertheless filter into and find expression in her work. Three Lives reveals its indebtedness to cinema in the way that it plays out modernist philosophical ideas about the fleetingness and ephemerality of the cinematic image at the level of its plot: dealing with the inability to know or to directly experience the present moment. "Melanctha" can also be linked to cinema in that Stein's technical experiments in this novella, and in works that followed it, was intended to create a sense of time as it is experienced in a film: a "continuous present", "a beginning again and again within a very small thing" (Composition as Explanation 1926, 26). Tender Buttons is an abstract work that seems to reproduce the sort of detached, mechanical "seeing" that is a function of the camera - though in this case it is a "camera" without human intention at the other end of it, left to pick up everything in front of it. What results is a jumble of visual detail that leaves the reader adrift in "waste and excess and mess" (Charney 1998, 33).

We might well ask to what degree can this sort of analysis be applied to other modernist works of fiction. Do we require a specific statement from the author about a work's relationship to cinema, as we are lucky enough to have with Stein, to entitle us to examine writings with the influence of cinema in mind? Stein, of course, was writing at the very dawn of cinema. Visual culture since then has exploded in ways that have surely been beyond the imagining of anyone at the turn of the last century: not only with the introduction of television, but the rise of personal computers and the internet, gaming, the development of smart phones, and so on. Current popular debate as to whether digital culture changes the way that our thought processes function, leading to a decline in our ability to concentrate on sustained tasks, and to a difference in the way we comprehend and consume information, seems to very much echo scholarly debate about the way in which the advent of cinema affected the sensory perception of human beings. It therefore seems surprising, and perhaps disappointing, that more 
comprehensive studies of the way cinema, and visual culture, have "infiltrated, contaminated and altered" (Murphet and Rainford 2003, 1) literary forms, have not been attempted.

\section{Bibliography}

Charney, Leo; Schwartz, Vanessa R. (eds). Cinema and the Invention of Modern Life. Berkeley, Los Angeles, London: University of California Press, 1995.

Charney, Leo. Empty Moments: Cinema, Modernity and Drift. Durham and London: Duke University Press, 1998.

Eliot, T.S. "The Waste Land" (1922). North, Michael (ed). The Waste Land: Authoritative Text, Contexts, Criticism. New York: W.W. Norton, 2001. 1 26.

Hoffman, Michael J; Murphy, Patrick D. "Critical Essays on American Modernism". New York: G. H. Hall and Co, 1992.

Marcus, Laura. The Tenth Muse: Writing about Cinema in the Modernist Period. Oxford: Oxford University Press, 2007.

Murphet, Julian. "Gertrude Stein and the Machinery of Perception". Murphet, Julian; Rainford, Lydia (eds). Literature and Visual Technologies: Writing After Cinema. Basingstoke and New York: Palgrave Macmillan, 2003. 67-81.

North, Michael. "Visual Culture". Kalaidjian, Walter (ed). The Cambridge Companion to American Modernism. Cambridge: Cambridge University Press, 2005. 177-194.

Sitney, P Adams. Modernist Montage: The Obscurity of Vision in Cinema and Literature. New York: Columbia University Press, 1990.

Stein, Gertrude. Three Lives (1905). DeKoven, Marianne (ed). Three Lives and Q.E.D. New York: W. W. Norton \& Company, 2006. 3-174.

--- Tender Buttons (1912). Meyerowitz, Patricia (ed). Gertrude Stein: Writings and Lectures 1911-1945. London: Peter Owen, 1967.158-199.

---"Composition as Explanation" (1926). Meyerowitz, Patricia (ed). Gertrude Stein: Writings and Lectures 1911-1945. London: Peter Owen, 1967. 21-30.

---“Portraits and Representation" (1934). Meyerowitz, Patricia (ed). Gertrude Stein: Writings and Lectures 1911-1945. London: Peter Owen, 1967. 98-122. 
--- "The Gradual Making of the Making of Americans" (1934). Meyerowitz, Patricia (ed). Gertrude Stein: Writings and Lectures 1911-1945. London: Peter Owen, 1967. 82-97.

Thompson, Kristin. "The Concept of Cinematic Excess." Rosen, Philip (ed). Narrative, Apparatus, Ideology. New York: Columbia University Press, 1986. 130-142.

Walker, Jayne L. The Making of a Modernist: Gertrude Stein from Three Lives to Tender Buttons. Amherst: University of Massachusetts Press, 1984.

Wood, Michael. "Modernism and Film". Levinson, Michael (ed). The Cambridge Companion to Modernism. Cambridge: Cambridge University Press, 1999. 217-232.

Woolf, Virginia. "The Cinema" (1926). "The Captain's Deathbed" and Other Essays. London: The Hogarth Press, 1950. 166-171. 